Int. J. Speleol. 15 (1986), pp. 3-13

\title{
ORIGINATION OF STONE FORESTS IN CHINA
}

\author{
Song Lin Hua *
}

\begin{abstract}
The stone forests are widely distributed in the tropical and subtropical climatic areas.

The stone forests may be divided into hilltop stone forest, hill slope stone forest and the stone forest in the depressions or valleys. The conditions for stone forest development should be (1) thick and pure limestone, (2) gentle dipping of limestone formation, generally less than $15^{\circ}$, (3) a lot of vertical joint and fissure networks, (4) the soil covering on the limestone surface inhomogeneous, thick in the fissures and thin on the rock top surface, and (5) the soil should be wet and contain rich organic materials and $\mathrm{CO}_{2}$.

In the above conditions, the stone teeth may develop to the stone forest. If lack of organic soil, low humidity and stable depth of soil erosion zone, the stone teeth is only been developed.
\end{abstract}

\section{RIASSUNTO}

Le "foreste di roccia" sono ampiamente distribuite nelle aree a clima tropicale o subtropicale. Esse possono esser suddivise in tre gruppi: le "foreste di roccia" sommitali, quelle di pendio e infine quelle nelle valli o nelle depressioni.

Perchè queste particolari forme carsiche abbiano la possibilità di svilupparsi è necessario che siano soddisfatte varie condizioni: (1) che il calcare sia puro e a stratificazione potente; (2) che l'immersione degli strati sia scarsa, generalmente meno di $15^{\circ}$; (3) che sia presente una fitta rete di fratture verticali; (4) che la copertura del suolo sia inomogenea, risultando spessa all' interno delle fratture e sottile o del tutto mancante sulla roccia; (5) il suolo deve essere molto bagnato e ricco di sostanze organiche e di $\mathrm{CO}_{2}$.

Sussistendo queste condizioni i "denti di roccia" possono svilupparsi sino a formare le "foreste di roccia". Nel caso che non vi sia suolo organico, o l'umidità sia bassa, o il suolo pedologico abbia uno spessore costante, solamente $\mathrm{i}$ "denti di roccia" possono esistere.

\section{INTRODUCTION}

The stone forest is defined as the group of stone pillars with over $5 \mathrm{~m}$ high. If less than 5 metres high, it is generally named stone teeth. The stone forests broadly distribute in the palaeotropical and subtropical climatic 


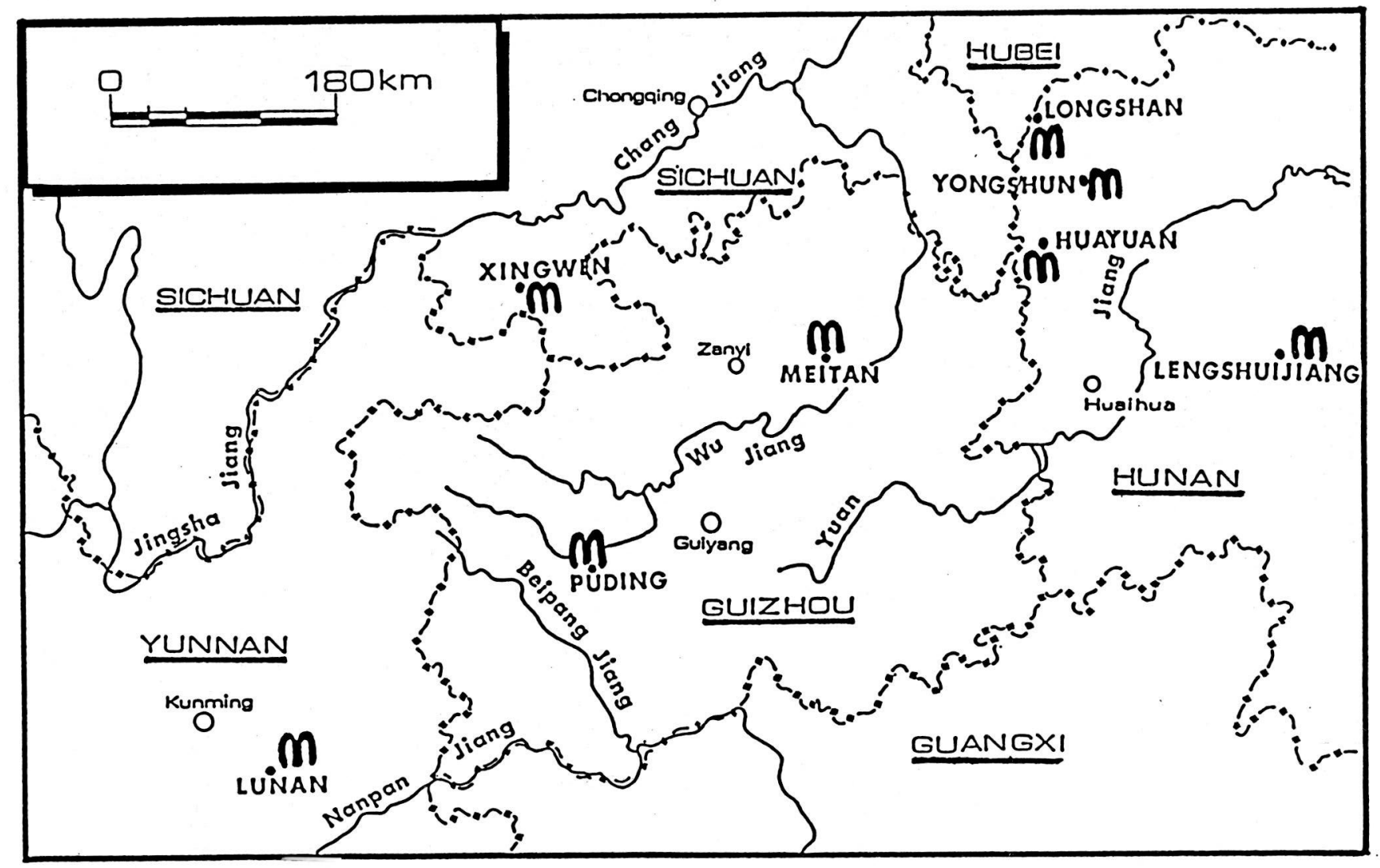


areas, such as in Lunan and Kunming of Yunnan Province, Puding and Meituan, Guizhou Province, Xingwen of Sichuan Province, Luota, Huayuan and Yongshun in Hunan Province (Fig. 1). The stone forests not only make the natural scenery more beauty, but also attract great numbers of karstologists and geographers to look into the origin of the forests.

There are a lot of hypothesis to explain the development of the stone forests. Ma Xirong (1936) suggested that it was resulted from the surface dissolution of limestone. Jie Xieyi (1966) described the development of stone forest should be with the conditions of: (1) very thick limestone; (2) the dipping of limestone formation must be near horizontal or gentle, generally the dipping angleis less than 10 degress; and (3) it develops in the vadose zone and commonly occurs in the watershed or near watershed areas. In "Karst Research of China" (1979), the author pointed out that the stone forests should be developed in the conditions of thick and gentle folded limestone, rainy and humid palaeoclimate and the palaeolandforms suitable to water vertically dissolving the limestone. Ren Meie (1980) stated that the stone forests are the collections of stone pillars separated by the dissolution along the fissures in horizontal and thick limestone, distribute on the slopes of basins nearly the water divide zones and are palaeotropical karst features. Chen, Song, and Sweeting (1985) recognized that the forests are dominantly produced by the subsoil erosion and retransformed by the dissolution of rainwater.

In the last few years, the author have investigated the stone forests in Lunan, Xingwen, Huayuan, Meituan, Yongshun and Lengshuijiang. Some conclusions may be worked out.

\section{LITHOLOGY AND GEOLOGICAL STRUCTURES FOR STONE FO- RESTS DEVELOPMENT}

The stone forests are dominantly developed in the thick pure limestones (Table 1). The Lunan Stone Forest mainly develops in the lower Permian Maokuo limestone, the maximum thickness of the bed may reach up to 30 metres and more. The Xingwen stone forest distributes in the third section of Maokuo $(\operatorname{Plm} 3)$, the biodetritus limestone with 5 metres of maximum bed thickness. The stone forest in Buermen Park, Yongshun County, Hunan Province, is developed in Ordovician dark pink limestone with 1-3 m layer thickness. Only the Xiaopaiwu forest in Huayuan County distributes in the dolomitic limestone with about 2 metres of single bed thickness. 
Table 1 Chemical compositions of limestone the stone forests developed in

\begin{tabular}{|ccrrrrr|}
\hline \multirow{2}{*}{ Site } & \multirow{2}{*}{ Formations } & \multicolumn{5}{c|}{ Composions (\%) } \\
& & $\mathrm{CaO}$ & $\mathrm{MgO}$ & $\mathrm{R}_{2} \mathrm{O}_{3}$ & $\mathrm{SiO}_{2}$ & loss \\
\hline \multirow{2}{*}{ Lunan, Yunnan } & Maokuo $\left(\mathrm{P}_{\mathrm{lm}^{1}}{ }^{1}\right)$ & 31.95 & 20.60 & 0.62 & 0.29 & 46.54 \\
& Maokuo $\left(\mathrm{P}_{\mathrm{lm}^{2}}{ }^{2}\right)$ & 56.12 & 0.05 & 0.32 & 0.29 & 43.42 \\
& Maokuo $\left(\mathrm{P}_{\mathrm{lm}}{ }^{3}\right)$ & 55.33 & 0.08 & 0.10 & 0.04 & 43.22 \\
Luota, Longshan, & & & & & & \\
Hunan & Maokuo $\left(\mathrm{P}_{\mathrm{lm}}\right)$ & 50.70 & 1.12 & 0.67 & 6.66 & 40.85 \\
& & 53.13 & 1.11 & 0.10 & 0.33 & 43.82 \\
& & 55.89 & 1.38 & 0.06 & 0.51 & 39.01 \\
\hline
\end{tabular}

Most of stone forests are developed in the gentle or horizontal limestone or dolomitic limestone, such as the dipping angle of Maokuo limestone in Lunan is about $10^{\circ}$ or less. Stone forest limestone in Xingwen varies in the range of $7-17^{\circ}$. Ordovician limestone in Buermen Park is less than $10^{\circ}$, the dipping angle of dolomitic limestone in Xiaopaiwu is less than $20^{\circ}$. It has been discovered that the high and huge stone forest is generally developed in the block of gentle limestone and the dipping angle less than $15^{\circ}$, while the shorter and smaller one in the limestone with the dipping higher than $15^{\circ}$. There is no possibility for stone forest to develop in the high dipping limestone (Group of Luota Karst, 1984).

The development of stone forest is closely related to joints and fissures. In the process of folding by the geoforce, the rigid limestone rocks is easyly broken as to form the vertical opening, joints and fissures which are nearly right crossed each other, or conjugated joints or fissures. For example, the Lunan stone forest is controlled by the net of joints and fissures of $\mathrm{N} 20^{\circ} \mathrm{W}, \mathrm{N} 50^{\circ} \mathrm{W}, \mathrm{N} .60^{\circ} \mathrm{E}$ and $\mathrm{EW}$ with $80-90^{\circ}$ dipping angles. Xingwen stone forest is affected by $\mathrm{N} 60-70^{\circ} \mathrm{W}, \mathrm{N} 35-25^{\circ} \mathrm{W}, \mathrm{N} 5-30^{\circ} \mathrm{E}$ and $\mathrm{N} 70$ $80^{\circ} \mathrm{E}$. The stone forest in Buermen Park is restricted by $\mathrm{N} 45^{\circ} \mathrm{W}, \mathrm{N} 80^{\circ} \mathrm{E}$ and $\mathrm{N} 65^{\circ} \mathrm{W}$ joints and fissures. Also Luota forest is dominantly controlled by the joints of $\mathrm{N} 50^{\circ} \mathrm{W}$ and $\mathrm{N} 30-40^{\circ} \mathrm{E}$.

\section{MAIN TYPES OF STONE FORESTS}

According to the covering conditions of the stone forests may be divides into 3 groups: (1) bared stone forest; (2) covered stone forest and (3) buried stone forest. Based on the geomorphological occurence of stone forests, it may be classified: (1) stone forest on the hill top (hilltop stone fo- 
rest); (2) stone forest in the depressions and valleys and (3) stone forest on the hill slope. There three types are described as follows:

(1)Stone forests in the depressions and valleys

The depression and valley-stone forests are characterized by the big dimensions, large distributing areas and stone pillars perfectly separated. Take Lunan sone forest for example, the Dashilin, Xiaoshilin and Motherson going for a walk etc are all developed in the karst depressions covered by one metre or more Quaternary sediments and with many karst dolines, sinkholes and subsurface drainage systems. The Sword Peak Pond is a typical karst natural lake. During the rain season, the water could be drained out by the underground drainage system, the groundwater table will rise up, sometime, the depression is flooded: for example, the tourist path in Unique Scenic spot depression was covered by over one metre of water. Another example is that there is a surface stream in the Xiaopaiwu karst depression which the stone forest develops in (Fig. 2).

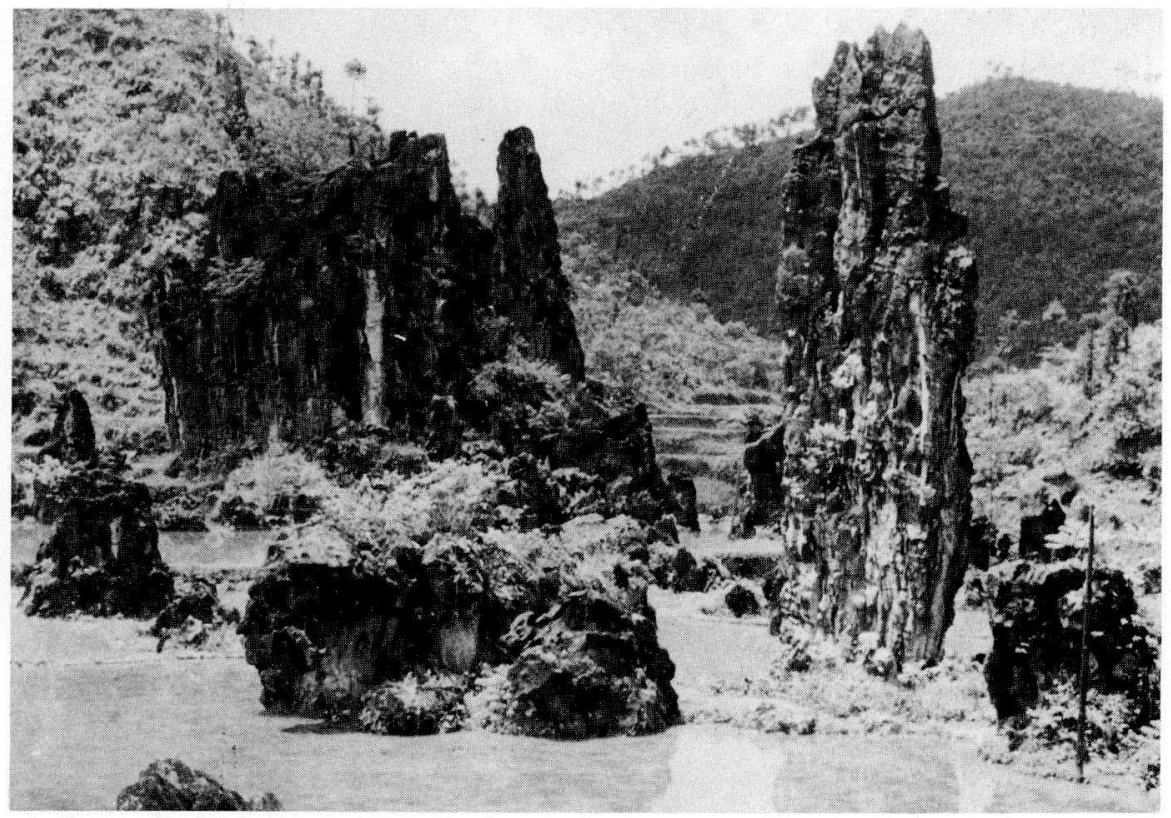

Fig. 2 - Stone forest in Xiaopaiwu karst depression, Huayuan, Hunan Province. 
(2) Hilltop stone forest

The pillars are grown up on the complete base (Fig. 3). The heigh of the indivial pillar is short, generally about 10 metres or little more, sometime may reaching up to 30 metres. The cover on the base rock is less than 1 $\mathrm{m}$. Commonly, the covering sediment is short, such as the New Stone Forest in Lunan.

(3) Hill-slope stone forest

The features are between the stone forests of depressions and hilltop. It is closely related to the stone teeth.

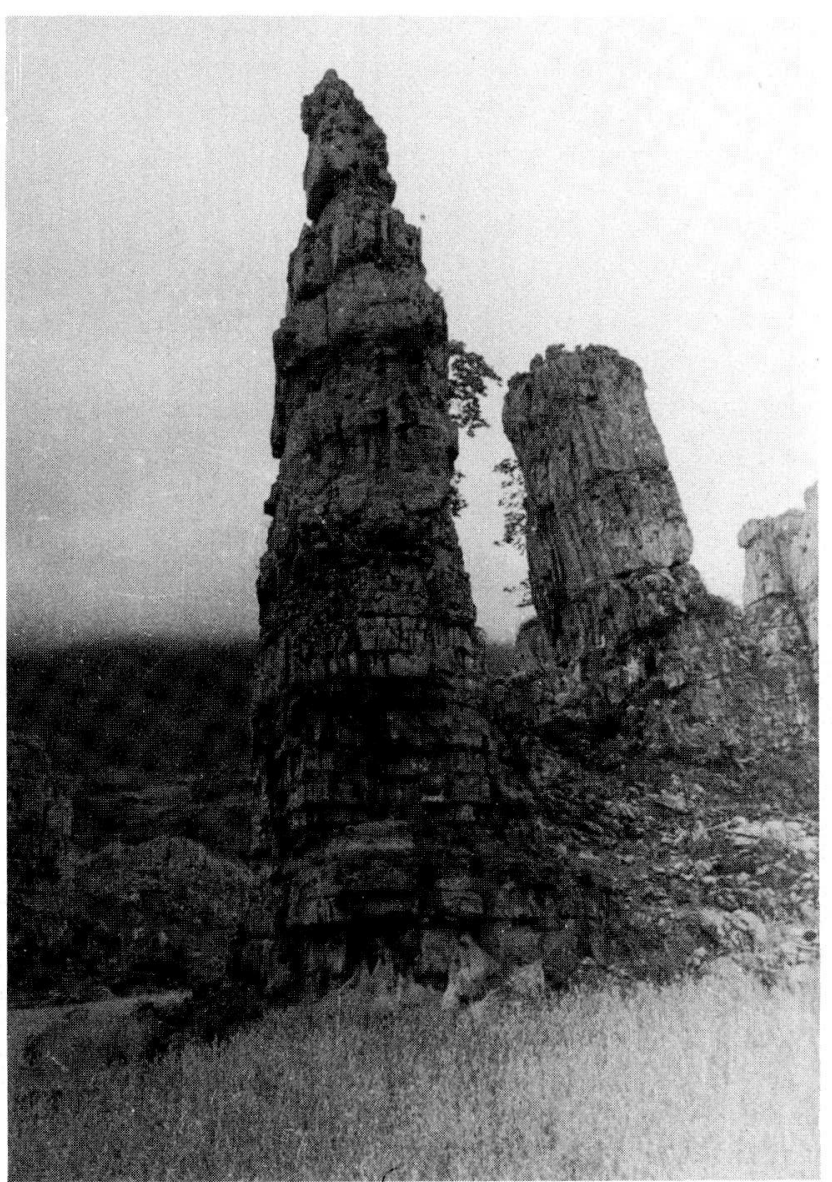

Fig. 3 - The stone pillars on one base. 


\section{ORIGINATION AND EVOLUTION OF STONE FOREST}

The main mechanism of the stone forest development is the subsoil erosion by soil water to enlarge the fissures and separate the rocky block.

Author paid attention to the relationship between the soilwater hydro-dynamics and the stone forest development during the investigation of the Xingwen stone forest. The weathered and corroded limestone is gradually covered by residuary materials or soil which contains aboundant humus and $\mathrm{CO}_{2}$. When the rainwater with little $\mathrm{CO}_{2}$ drops on the ground surface, it will absorb the $\mathrm{CO}_{2}$ of soil air and released directly from the biogences on one hand, on other hand, it penetrates downward in the soil.

The penetrating water takes two ways, one moves down as the soil water, the other, as the surface water, moves in the contact zone between the limestone surface and soil (Song, 1985). The surface flow is the main dynamic factor to enlarge the vertical joints and fissures, while the erosion ability of the surface flow will be greatly losen after flowing the distance of about $2-3 \mathrm{~m}$. In the section of strong erosion, the fissures and joints are rapidly enlarged and widened. In the part of less erosion ability, the water way is narrow. Therefore, the subsoil erosion feature is like a long funna. Due to the space of fissure narrowing in the vertical direction, a part of soil water will flow to the contact and mix with the saturated surface flow. So the mixing flow will get new erosion ability to corrode the limestone, and the feature like the string of beads may be discovered (Fig. 4). If the elevations of two neighbour soil-filled pits is different, the soil water might flow from the higher one to the lower one through the fissure or joint. In the rainy season, a temporary underground water saturation zone is formed and a rather horizontal subsoil tube would be developed (Fig. 5). Though under the gravitation the velocity of vertical penetrate flow is higher than that of horizontal flow and the horizontal flow is temporary. The erosion of horizontal flow containing high $\mathrm{CO}_{2}$ content is very strong.

The slope erosion makes much soil with great humic and organic materials in the depression bottoms. The speed of stone forest development in depression is 10 times higher than that of the forest on the hilltop (Yan Qingtong, 1982), tahta means that even if stone forests on the hilltop and in the depressions may simultaneously develop the size of stone forest but the hilltop is smaller than the depression-stone forest normally $20-30 \mathrm{~m}$, max. $35 \mathrm{~m}$ high. Generally, the base of hilltop stone forest is exposed, the main mechanism is the rainwater erosion. Sometimes, the weathering is stronger 
than the stone forest development. Thus, the Xingwen stone forest on the hilltop is the residual one with only 1 or 2 pillars on one hill.

The erosion of rainwater on the top of stone pillars has created the solutional cups, bows, basins, small gully and flut the depth of the both is from several $\mathrm{mm}$ to $1 \mathrm{~m}$. The rainwater erosion is playing important role or shortening the stone forest. From this point of view, the speed of stone forest development is determined by the soil water and surface water but not by the rainwater.

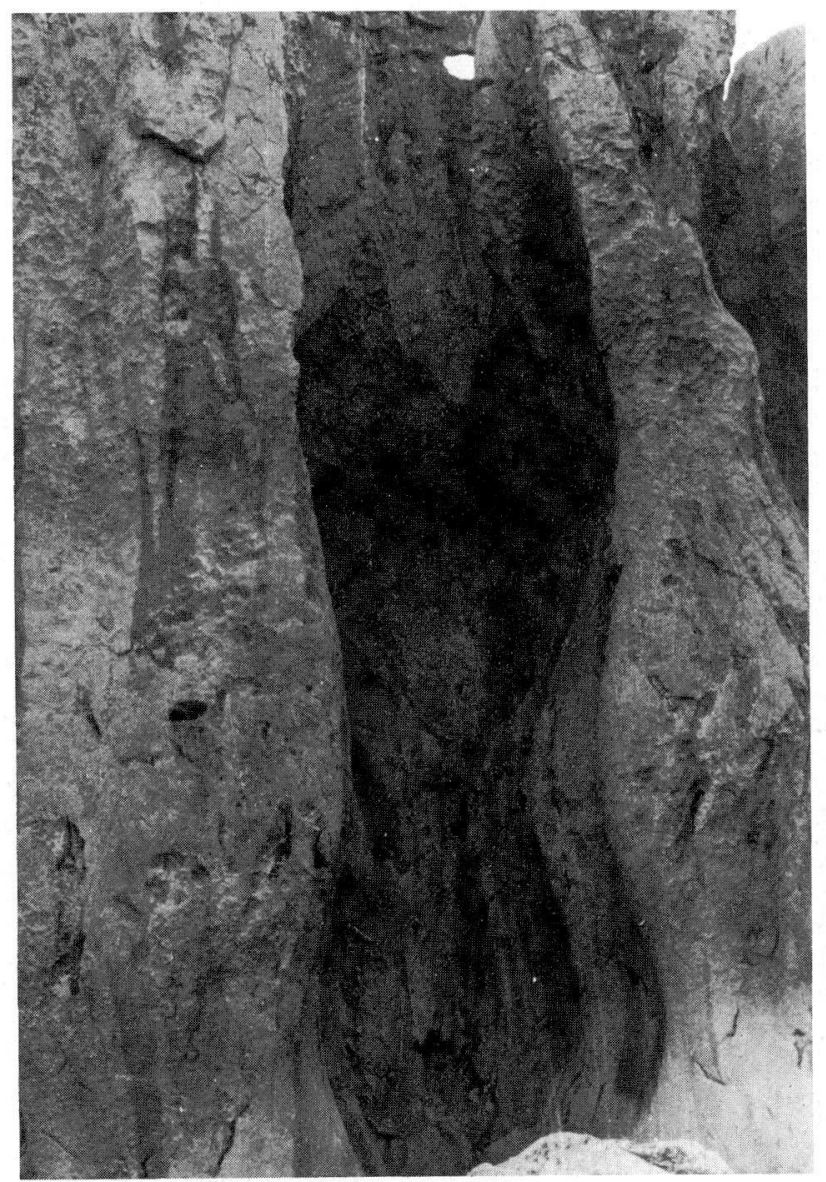

Fig. 4 - Subsoil erosion pits like the string of 2 beads. 


\section{STONE TEETH AND STONE FOREST}

There are some different point of view about the relationship between stone teeth and stone forest. Someone state that the stone forest is developed from the stone teeth (Zhang Shuyue, 1984). The others argued that it is possible for stone forest developing from stone teeth, but also stone teeth may develop from stone forest.

In fact, the relationship between stone teeth and stone forest is very

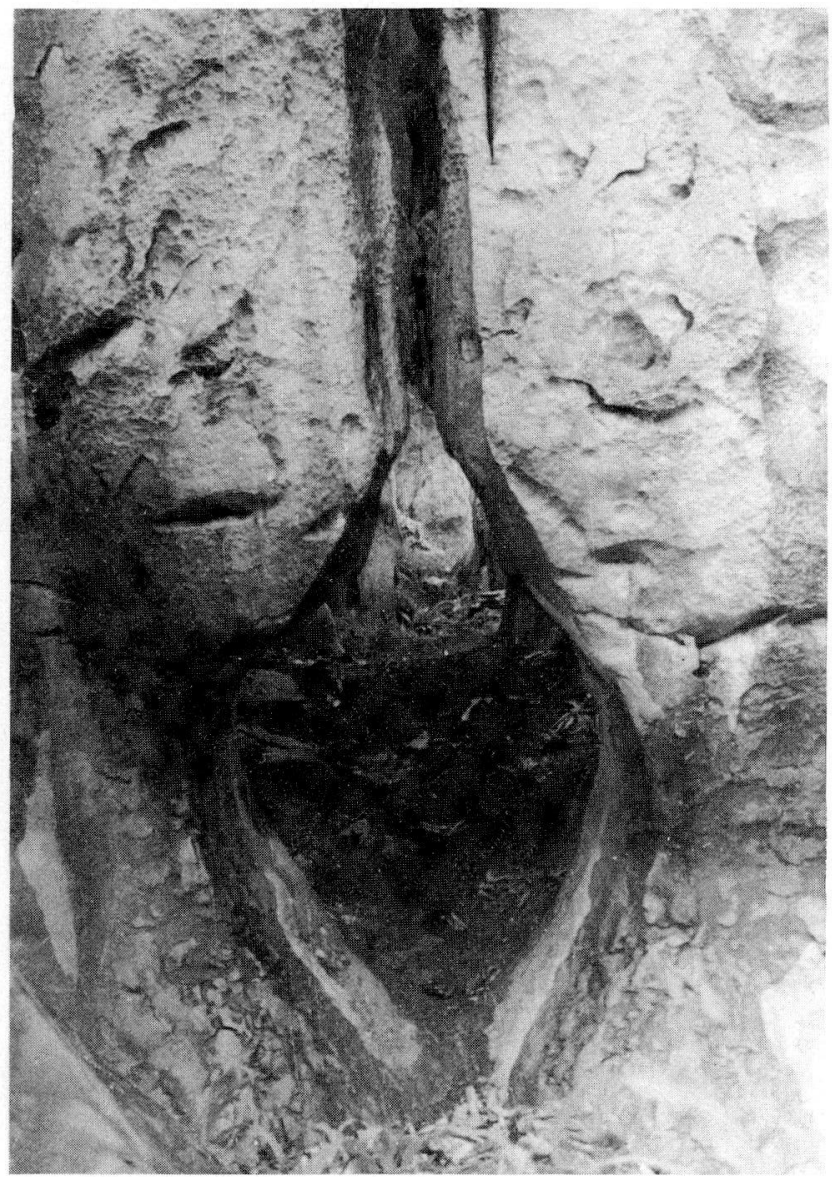

Fig. 5 - Horizontal subsoil erosion tube. 
complicated. The hypothesis of stone forest developing from the stone teeth is correct, but it only takes place in the position with gentle dipping and thick limestone with a lot of vertical joints or fissure nets, and covered by the organic and humid soil. The Lunan stone forest is a good example. In the place where the cover is very thick and the soil is well conservated, the depth of subsoil water erosion is stabilized, le limestone is homogeneously dissolved under the soil though the intensity of the erosion in the joints and fissures is comparable high. Hence, it is possible just the stone teeth develops. If the soil inhomogeneously covers the limestone and soil ground surface is contineously lowered down, the strong erosion zone gradually goes down too. The thickness of soil layer is not uniform everywhere, that means in the joint and fissure zone, the soil is thick but in other part thin. In the evolution process of stone forest, the joint and fissure are
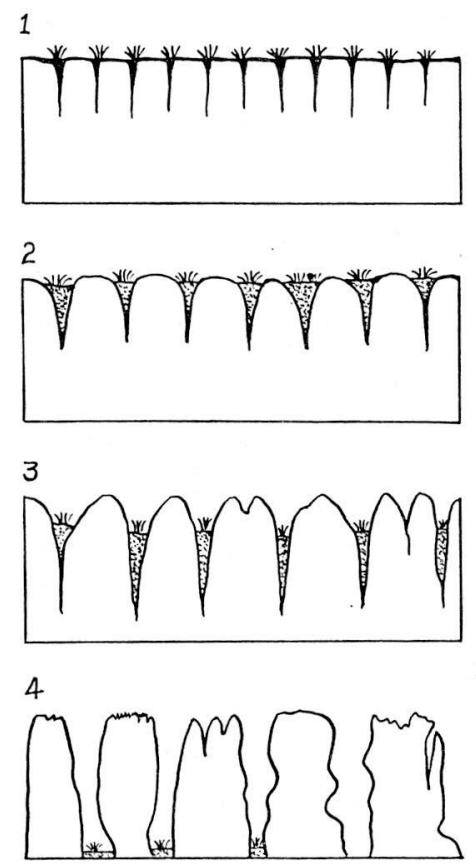

Fig. 6 - The evolution stage of the stone forest

1. original fissured limestone

2 and 3 subsoil erosion to enlarge the fissures and form the stone teeth

4. stone forest development 
gradually and strongly enlarged and deepened. The erosion intensity in the thin soil cover zone or the composed places is weak. The large fissure is the main water moving way, there is generally developing the sinkhole or shaft. Thus, the stone teeth may evolute to the stone forest (Fig. 6).

In the place of the dipping more than $15^{\circ}$, the joints or fissures probably are developed well but they are not vertical on the ground surface. With the enlarging of joints and fissures, the upper part of limestone block is commonly cut off and the heigh of the limestone block is restricted. In other words, the stone teeth is the principle karst features.

If the soil contains high content of calcareous materials, the soil water is already satured before it reaches on the contact surface of limestone with soil. Thus the joints and fissures are widen very slow and it is very difficult for stone forest to develop.

If the soil water erosion zone is very stable after the stone forest developed, the base of the forest is erosed for a long time and the stone pillars will fall down. On the base of the fall pillar will develop new stone teeth.

\section{REFERENCES}

Chen Zhi PING, Song Lin Hua and M. M. Sweeting, 1985: The pinnacle karst of the Stone Forest Lunan, Yunnan, China: an example of a sub-jacent karst. In: New Directions in Karst (in press), Geobooks, Norwich.

JIE XIEYI, 1966: Preliminary study on types of karstic formations, fossil karst and conditions for karst development. In: Selected Papers of The First National Hydrogeological and Engineering Geological Symposium, No. 2 (Karst Issue) China Industrial Publisher, 1966.

KARST RESEARCH GROUP, Institute of Geology, Academia Sinica: Karst Research of China, Scientific Press, Beijing, 1979.

MA XIRONG, 1936: Preliminary investigation on the Lunan Stone Forest Yunnan, from the geomorphological view. Theoretical Review, Vol. 1, No. 1.

ReSEARCH Group of LuOTA KarST GeOlogy: Study on Karst Development and Water Resource Assessment in Luota Area. Geological Publishing House, Beijing, 1984.

SONG LIN HUA, 1985: Evolution of karst depressions and its bydrogeological significance (unpublished).

YE QINGTONG, 1982: Stone forest and karst (unpublished).

ZHANG SHUYUE, 1984: The development and evolution of Lunan Stone Forest. Carsologica Sinica, Vol. 3, No. 3, pp 78-87. 